\title{
FDI and economic growth in the GCC: Does the oil sector matter?
}

\author{
Mohamed Elheddad ${ }^{1} \bullet$ Mohga Bassim ${ }^{2} \bullet$ Rizwan Ahmed $^{3, *}$ \\ ${ }^{1}$ Department of Management, Huddersfield Business School, University of Huddersfield, UK \\ ${ }^{2}$ University of Buckingham, $U K$ \\ ${ }^{3}$ University of Birmingham, $U K$
}

Received: 25 October 2020

Revised: 9 February 2021

Accepted: 10 February 2021

\begin{abstract}
This paper investigates the impact of economic sectors' foreign direct investment (FDI) on economic growth by validating the resource curse hypothesis in the Gulf Cooperation Council (GCC) countries. Applying OLS (Fixed and Random effects), Instrumental Variables (IV) and Limited Information Maximum Likelihood (LIML) estimations, empirical results indicate that resource-FDI inflows hinder economic growth in the GCC economies, while non-resource FDI has an insignificant effect on growth. Moreover, the total Greenfield FDI inflows deter economic growth in GCC economies. These results give evidence on the crowding-out effect of resource-FDI. This paper opens new insights for policymakers in designing a comprehensive policy on direct FDI inflows (resource and non-resource) to stimulate growth for attaining sustainable economic development for the long run.
\end{abstract}

Keywords: FDI; economic growth; natural resource curse; instrumental variables (IV); limited information maximum likelihood (LIML)

JEL Classification Codes: F21, F23, F43, C23

\section{Introduction}

FDI has been seen as essential for economic growth, Wallis (1968). It has been perceived as a means for technology transmission and provision of capital Borensztein et al. (1998). However, several recent studies argue that FDI may inhibit economic growth. Carkovic and Levine (2002) observed that FDI does not generate a robust positive effect on economic growth and Sadik and Bolbol (2001) concluded that FDI has a negative influence on GDP growth in Saudi Arabia. The positive impacts of FDI are restricted in the host country by the human capital stock Borensztein et al. (1998), Blomström et al. (2001), openness to trade Balasubramanyam et al. (1996) and financial markets development Alfaro et al. (2004). Chanegriha et al. (2020) provided a summary of the growth theories for the empirical work on FDI in relation to

\footnotetext{
${ }^{*}$ Corresponding author. E-mail: r.ahmed.6@bham.ac.uk.

Citation: Elheddad, M., Bassim, M., and Ahmed, R. (2021) FDI and economic growth in the GCC: Does the oil sector matter?, Economics and Business Letters, 10(3), 164-177.
}

DOI: 10.17811/ebl.10.3.2021.178-190 
growth, using a heterogeneous panel test data for 136 countries over a period of 36 years. They broadly concluded that FDI does not promote growth.

There are several determinant for FDI impact on economic growth in the literature. Sala-iMartin (1997) in his analysis, uses as many as 60 variables which were found earlier to be significant. El Heddad (2016) uses inflation rate, political instability, Corruption Perception Index and labour force for GCC and found that natural resources have a negative association with FDI inflows.

This study investigates the causality between FDI inflows in different economic sectors and economic growth, in the GCC oil-exporting economies Bahrain, Kuwait, Oman, Qatar, Saudi Arabia and the United Arab Emirates, using panel data for the period 2003-2013. The study is using FDI inflows for resource and non-resource sectors, saving, gross fixed capital formation and GDP per capita growth. The Extreme Bound Analysis (EBA) or the recent Dynamic Extreme Bound Analysis (DEBA) proposed by Pham and Wongsurawat (2020), may be used in a future research to better identify the determinants which should be used in the analysis. This should reduce the sensitivity due to the selection of a limited number of variables from the large number of determinants found in different literature, and in view of the controversy on which of these determinants are effective.

Generally, FDI-growth relationship studies concentrated on the aggregate level of FDI. Kolstad and Villanger (2008), Cazzavillan and Olszewski (2012), however, concluded that investment in certain sectors (such as mining) might crowd out FDI in other sectors, such as manufacturing. Multinational corporations (MNCs), especially in the resource sector, can negatively affect domestic firms' market share via high levels of productivity Haddad and Harrison (1993), Aitken and Harrison (1999). Also, Campos and Kinoshita (2003) found that FDI in manufacturing and services results in better technological benefits more than FDI in the primary sector. Alfaro (2003) examined the influence of FDI in primary, manufacturing, and service sectors on economic growth for developing and developed countries from 1981 to 1999. The results showed that the impact of FDI on economic growth is negative in the primary sector (including mining), and positive in the manufacturing sector. Aykut and Sayek (2007) used a panel of ASEAN, Latin American and OECD countries and proved a negative association between FDI and economic growth in the primary sector. Khaliq and Noy (2007) used

time-series data for Indonesia and concluded that FDI in the mining and quarrying sector has a negative effect on economic growth.

Resource-rich countries attract more FDI inflows into the capital intensive resource sector which is found to deter FDI in other sectors Poelhekke and van der Ploeg (2013). The GCC economies attracted FDI during the boom of oil prices (2002-2008). FDI inflow grew by 15 percent (2000-2013), accounted for approximately 17 percent of GDP and increased to 27.1 percent of GDP - Table 1.

This study utilises economic sectors dataset on Greenfield FDI inflows to analyse its effects on resource and non-resource sectors. Also, it provides a new mechanism to explain whether FDI inflows can be an additional channel of the natural resource curse. It complements the previous works on sector-level FDI impact on economic growth but differs in investigating this relationship in the context of the natural resource curse. Furthermore, it provides a greater understanding of economic growth determinants in the presence of the resources curse hypothesis. The main quest of this empirical work is whether FDI promotes or deters economic growth. We expect a negative association between resource-FDI and economic growth and a resource curse ${ }^{I}$.

\footnotetext{
${ }^{1}$ The resource curse is the term used to describe the failure of resource-abundant countries to benefit from natural wealth.
} 
Table 1. FDI inflows in GCC (2000-2013).

\begin{tabular}{lrrr}
\hline \hline & $\mathbf{2 0 0 0}$ & $\mathbf{2 0 1 0}$ & $\mathbf{2 0 1 3}$ \\
\hline Total FDI inflows (in Million Dollars) & 412.76 & 2533.84 & 2658.11 \\
FDI inflow/GDP per cent (Average) & 16.8 & 29.8 & 27.1 \\
$\begin{array}{l}\text { Greenfield FDI inflows as a per cent of the West Asia re- } \\
\text { gional total }\end{array}$ & $\mathrm{NA}^{2}$ & 85.5 & 82.7 \\
\hline \hline
\end{tabular}

Source: Author's calculations based on the UNCATD data, 2016.

Figure 1. Correlation of resource (oil) Greenfield FDI and economic growth in GCC countries (2003-2013).

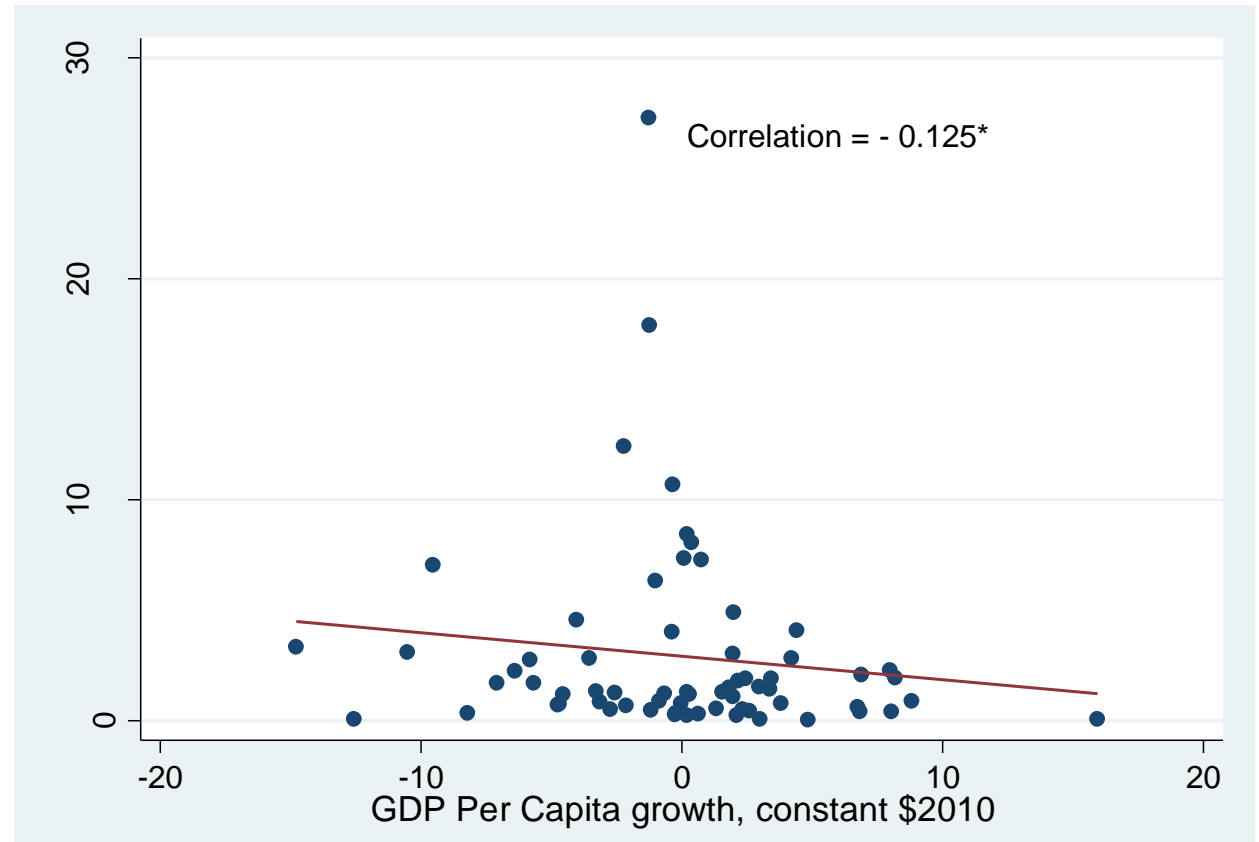

Source: STATA outcome based on UNCTAD and Word Economic Indicators (World Bank) datasets.

Figure 2. Correlation between non-resource (non-oil) Greenfield FDI and Economic Growth in GCC countries (2003-2013).

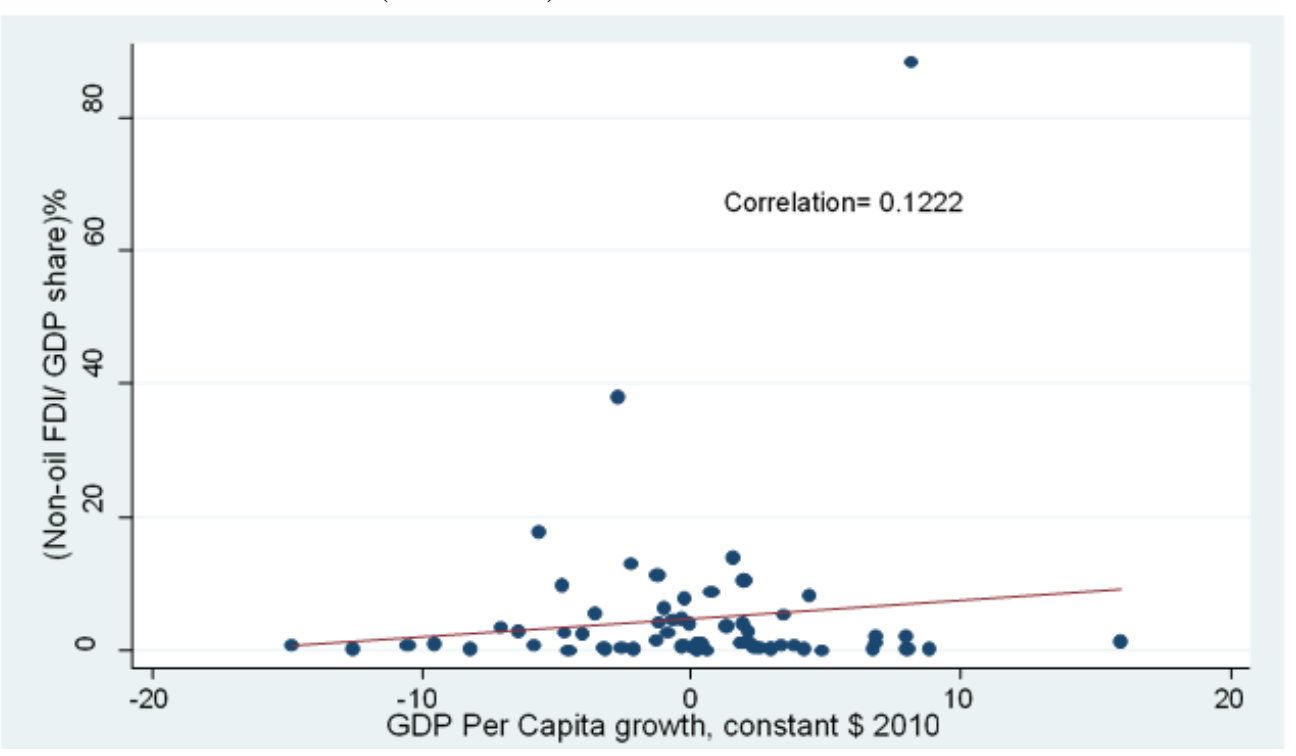

Source: STATA outcome based on UNCTAD and Word Economic Indicators (World Bank) datasets.

\footnotetext{
${ }^{2}$ Not available.
} 
The correlation coefficient $(-0.125)$ in Figure 1, indicates that there is a significant and negative association between resource-related FDI (oil) and economic growth in the GCC economies, and reflects the concept that greater concentration of FDI in resource-based industries leads to low levels of economic growth. However, for the non-resource sectors, the coefficient is $(0.122)$ in Figure 2, which indicates positive economic growth. This is in line with past studies Alfaro (2003), Vu and Noy (2008).

The authors note that the study period was characterised by a stable and fast increase in oil prices except for 2009 when there was a price shock following the world economic crises. The prices, however, bounced back to its previous level by 2011. There have been another price shock in 2014, which continued and undoubtedly had serious effects on all economies in the GCC. In oil exporting countries oil price reduction shocks can be expected to reduce FDI to resource sector, and affect investment and economic growth. This is in line with Nasir et al. (2020), who has shown that oil price shocks affect several financial and economy variables including inflation targeting and exchange rate. The Authors have therefore limited the study period to be up to 2013 only.

The aim of this paper is to investigate the separate effects of resource and non-resource sectors' FDI on economic growth, and validate the resource curse hypothesis in GCC. Also, investigate the effect of total Greenfield FDI inflows on Growth in GCC economies, and the possibility of crowding out effects of the resource FDI. It contributes to current literature by investigating the effect on resource vs. non-resource sector and provide the policy makers with the necessary backing to encourage policies to diversify FDI to non-resource economic activities, i.e. to Manufacturing and service sectors.

The paper structure is as follows; Section 2 discusses data sources and some issues related to the methodology, Section 3 the empirical results and Section 4 the study conclusions and policy implications.

\section{Model and methodology}

\subsection{Model specification}

We explore the FDI-economic growth relationship in GCC economies as a sample of oil-rich countries, adopting an empirical model similar to that used in previous studies. Alfaro (2003) and Borensztein et al. (1998), formulated the model as,

$$
\begin{aligned}
& \text { Growth }_{i, t}=\alpha_{0}+\alpha_{1} \text { Intial GDP }_{t}+\alpha_{2} F D I_{i, t}+\alpha_{3} X_{i, t}+\mu_{i}+\varepsilon_{1 i, t} \\
& \text { Growth }_{i, t}=\beta_{0}+\beta_{1} \text { Intial GDP }_{t}+\beta_{2} F D I_{i, t, j}+\beta_{3} X_{i, t}+\mu_{i}+\varepsilon_{2 \mathrm{i}, t}
\end{aligned}
$$

Where:

- Growth ${ }_{i, t}$ : Annual growth of real GDP per Capita (constant at 2010, US dollars),

- Initial GDP $P_{t}$ : Initial GDP per Capita in year t (2003)

- $F D I_{i, t}$ : Total Greenfield FDI inflows/GDP to country $\mathrm{i}$ in year $\mathrm{t}$.

- $F D I_{i, t, j}$ : Greenfield FDI inflows/GDP in the country $\mathrm{i}$ in year $\mathrm{t}$ to sector $\mathrm{j}, \mathrm{j}$ indicates resource and non-resource sectors.

- $X_{i, t}$ : A vector of control variables.

- $\alpha$ (alphas) and $\beta$ (betas): Estimated parameters.

- $\varepsilon_{1, t}$ and $\varepsilon_{2, t}$ : Errors terms of total FDI and economic sectors' FDI (resource and non-resource) respectively,

- $\mu_{i}$ : The fixed time and country effect.

- The fixed effect term: Unobserved (country level) effects "country heterogeneity".

We hypothesise that FDI in the resource sector has a negative effect on economic growth, and in non-resource FDI has insignificant or little effect. Also, the impact of total FDI inflows 
on growth is negative. This gives support to the hypothesis that FDI can result in a natural resource curse.

\subsection{Methodology}

Panel data techniques Hsiao (2007) are used to improve the precision of the estimation applied to the proposed models for the sample of six oil-dependent economies in the GCC.

The GCC economies have common characteristics such as language and ruling regimes, but they are heterogeneous in terms of regulations, and some economic policies. Panel data controls this heterogeneity, which is captured by $\alpha_{i}$ in the models for each economy.

This study reports both results of Fixed Effect (FE) and Random Effect (RE) estimations Cameron (2010), Baltagi (2008), using the statistical software STATA.15. The choice between FE and RE is subject to the specification of the Hausman test Hausman (1978).

The Generalised Method of Moments (GMM) is a commonly used estimators in panel data, Roodman (2009) and Agyapong and Bedjabeng (2019). However, Arellano and Bond (1991) and Blundell and Bond (1998) showed it has some limitations, and therefore will not be used in this paper. Nasir et al. (2019), used Dynamic Ordinary Least Squares (DOLS) and Fully Modified OLS (FMOLS) techniques for their panel data analysis to investigate the role of financial development, economic growth and FDI on climate changes.

One of the main concerns in panel data analysis is the endogeneity, which causes the OLS assumption to fail Baltagi (2008) Wooldridge (2010). Finding a valid instrumental variable is difficult. Therefore, the authors will depend on the instruments suggested by the previous studies and test the validity and strength of these instruments.

This study adopts the instrumental variable estimation (IV), which offers a consistent estimation under the strong assumption that an exogenous instrument exists (valid IV) which satisfies $E(\varepsilon \mid \mathrm{Z})=0$. This assumption implies that $E\left(\mathrm{y}_{\mathrm{i}, \mathrm{t}}-\mathrm{X}_{\mathrm{i}, \mathrm{t}} \beta \mid \mathrm{Z}\right)=0$.

The general model in Eq. (3) assumes that $X$ is an endogenous variable need to be instrumented by $\mathrm{Z}$. The first stage equation (reduced form), containing only the exogenous variable $(Z)$ on the right-hand side:

$$
X_{i, t}=\mu+Z_{i, t} \gamma+\alpha_{i}+\varepsilon_{i t}
$$

Model (3) can be;

$$
y_{i, t}=\mu+X_{i, t}^{\prime} \beta+\alpha_{i}+\varepsilon_{i t}
$$

- $\quad X^{\prime}$ : Residuals of Eq. (3). This model mitigates endogeneity through regressing y on $\mathrm{X}$ using instrument $\mathrm{Z}$.

The IV estimator does not require a specific number for the sample size; however, it requires valid and strong instruments. Several tests have been introduced to check the instruments' strength. In this paper, we use the Cragg-Donald (C-D) statistic, among other diagnostic tests, to decide whether the instruments are weak. Andrews and Stock (2005) have compiled critical values for the Cragg-Donald $\mathrm{F}$ statistic for several different estimators (including IV and Limited Information Maximum Likelihood (LIML). When exceeding the threshold that Andrews and Stock (2005) provide, it can be stated that the instruments are strong.

Also, IV estimations can show severe finite-sample bias Dobson and Ramlogan-Dobson (2012). Alternatively, LIML estimation is performed here. The LIML method, proposed by Anderson and Rubin (1950) and Anderson et al. (2010), is well suited for dynamic panel estimations. The advantages of LIML over other approaches are that it is virtually unbiased, and is reliable in the case of small sample sizes, Blomquist and Dahlberg (1999).

The authors report the FE, RE and the Hausman test results. Also, they applied IV estimations and reported the LIML results as an extra estimation in the case of weak instruments. 
Table 2. Descriptive statistics.

\begin{tabular}{|c|c|c|c|c|c|c|c|}
\hline Variable & & Mean & $\begin{array}{l}\text { Std. } \\
\text { Dev. }\end{array}$ & $\overline{M i n}$ & $\overline{M a x}$ & Observations & \\
\hline \multirow{2}{*}{$\begin{array}{l}\text { FDI stock Inflows } \\
\text { /GDP }\end{array}$} & overall & 24.4 & 19.86 & 0.69 & 83.91 & $\mathrm{~N}=$ & 66 \\
\hline & between & & 20.24 & 5.39 & 64.06 & $\mathrm{n}=$ & 6 \\
\hline \multirow{2}{*}{$\begin{array}{l}\text { Greenfield FDI inflows } \\
\text { to non-oil sector/GDP }\end{array}$} & overall & 2.91 & 4.47 & 0.04 & 27.31 & $\mathrm{~N}=$ & 66 \\
\hline & between & & 3.22 & 0.6 & 9.15 & $\mathrm{n}=$ & 6 \\
\hline \multirow{2}{*}{$\begin{array}{l}\text { Greenfield FDI inflows } \\
\text { to oil sector/GDP }\end{array}$} & overall & 4.64 & 11.92 & 0 & 88.12 & $\mathrm{~N}=$ & 66 \\
\hline & between & & 5.57 & 0.2 & 15.39 & $\mathrm{n}=$ & 6 \\
\hline \multirow[t]{2}{*}{ Saving/GDP } & overall & 45.56 & 14.77 & 24.1 & 74.61 & $\mathrm{~N}=$ & 66 \\
\hline & between & & 14.63 & 32.57 & 70.77 & $\mathrm{n}=$ & 6 \\
\hline \multirow{2}{*}{$\begin{array}{l}\text { Gross Fixed Capital } \\
\text { Formation/GDP }\end{array}$} & overall & 24.53 & 7.19 & 12.83 & 46.02 & $\mathrm{~N}=$ & 56 \\
\hline & between & & 6.34 & 16.53 & 35.48 & $\mathrm{n}=$ & 6 \\
\hline \multirow{2}{*}{$\begin{array}{l}\text { GDP per Capita } \\
\text { growth (constant } 2010 \\
\text { US \$) percent }\end{array}$} & overall & -0.02 & 5.23 & -14.79 & 15.95 & $\mathrm{~N}=$ & 56 \\
\hline & between & & 2.05 & -3.75 & 2.21 & $\mathrm{n}=$ & 6 \\
\hline
\end{tabular}

\subsection{Data}

Real GDP per Capita as a measure of economic growth is obtained from the World Development Indicators, as the main variable of interest. The effect of FDI inflows on economic growth is troubled by the challenges in separating FDI inflows into sectors, and none of the international organisations offers FDI sector-level data. Greenfield FDI, which flows into a resource $^{3,4}$ Sector, follow the Financial Times intelligence unit, verified FDI dataset, for annual observations from 2003 to 2013 (constant 2010 US\$).

Widely used control variables as determinants of economic growth including population growth Alfaro et al. (2004); Azman-Saini et al. (2010) and gross fixed capital formation as a share of GDP (as a proxy of investment) Borensztein et al. (1998) are introduced. Table 2 reports the descriptive statistics of the used variables.

\section{Empirical results and discussions}

\subsection{Disaggregate FDI- economic growth nexus}

Wang (2009) argued that the reason for the ambiguous outcomes of FDI on economic growth is the use of aggregate FDI inflows rather than economic sectors' FDI. This negative impact of FDI on economic growth motivates the researcher to explore its source, and this section analyses this impact.

Table 3 presents the results of FE and RE estimations for the impact of resource and nonresource FDI on GDP per Capita growth. Regression 1, Table 3 reports the FE results and shows that FDI in the resource industry has a significant and negative effect on GDP per Capita growth. The choice between FE and RE models is subject to the Hausman test. The Chi2-squared statistic of the Hausman test and p-value reject the null hypothesis. Therefore, the FE model is appropriate. The -0.205 coefficient implies that a 1 percent increase in resource-FDI is associated with a 0.205 percent decrease in GDP per Capita growth. The relationship between non-resource-FDI and economic growth is positive but insignificant.

\footnotetext{
${ }^{3}$ The resource sector is the sector that uses or exploits natural resources.

${ }^{4}$ The non-resource sector is the sector that produces manufactured goods and services.
} 
Table 3. Economic Sectors' FDI and economic growth estimations (fixed and random).

\begin{tabular}{|c|c|c|c|c|}
\hline & $\begin{array}{r}(1) \\
F E \\
\text { GDP per } \\
\text { Capita } \\
\text { growth }\end{array}$ & $\begin{array}{r}(2) \\
R E \\
\text { GDP per } \\
\text { capita growth }\end{array}$ & $\begin{array}{r}(3) \\
F E \\
\text { GDP per } \\
\text { capita growth }\end{array}$ & $\begin{array}{r}(4) \\
R E \\
\text { GDP per } \\
\text { capita growth }\end{array}$ \\
\hline GDP initial & $\begin{array}{r}-0.800^{* * *} \\
(0.113)\end{array}$ & $\begin{array}{r}-0.082 \\
(0.060)\end{array}$ & $\begin{array}{r}-0.822 * * * \\
(0.139)\end{array}$ & $\begin{array}{l}-0.117 * \\
(0.060)\end{array}$ \\
\hline $\log (F D I R / G D P)$ & $\begin{array}{r}-0.205 * * * \\
(0.046)\end{array}$ & $\begin{array}{c}-0.068 * \\
(0.035)\end{array}$ & & \\
\hline Log (capital formation) & $\begin{array}{r}0.090 \\
(0.073)\end{array}$ & $\begin{array}{r}0.077 \\
(0.057)\end{array}$ & $\begin{array}{r}0.137 \\
(0.089)\end{array}$ & $\begin{array}{r}0.120 * * \\
(0.057)\end{array}$ \\
\hline Log (population Growth) & $\begin{array}{r}-0.032 \\
(0.030)\end{array}$ & $\begin{array}{r}0.001 \\
(0.041)\end{array}$ & $\begin{array}{r}-0.006 \\
(0.036)\end{array}$ & $\begin{array}{r}0.006 \\
(0.045)\end{array}$ \\
\hline Log (government consumption) & $\begin{array}{r}0.497 * * * \\
(0.107)\end{array}$ & $\begin{array}{r}-0.064 \\
(0.046)\end{array}$ & $\begin{array}{r}0.309 * * \\
(0.119)\end{array}$ & $\begin{array}{l}0.086^{*} \\
(0.046)\end{array}$ \\
\hline $\log (F D I N R / G D P)$ & & & $\begin{array}{r}0.008 \\
(0.020)\end{array}$ & $\begin{array}{r}-0.018 \\
(0.020)\end{array}$ \\
\hline _cons & $\begin{array}{r}-2.566^{* * * *} \\
(0.714)\end{array}$ & $\begin{array}{r}0.327 \\
(0.254) \\
\end{array}$ & $\begin{array}{r}-1.052 \\
(0.787) \\
\end{array}$ & $\begin{array}{r}0.311 \\
(0.271)\end{array}$ \\
\hline Observations & 54 & 54 & 54 & 54 \\
\hline$R$-squared & 0.676 & & 0.523 & \\
\hline Hausman test & 85.91 & & 39.55 & \\
\hline Chi2 (p-value) & $(0.000)$ & & $(0.000)$ & \\
\hline Obs. & 54 & 54 & 54 & 54 \\
\hline
\end{tabular}

Note: Standard errors are in parentheses $* * * \mathrm{p}<0.01, * * \mathrm{p}<0.05, * \mathrm{p}<0.1$

The negative impact of oil FDI is less when the RE model is applied (-0.068), and significant only at a 10 percent level of significance. Further, FDI inflows to non-resource sectors have an insignificant contribution to economic growth in these economies. The results show that the negative impact of resource-FDI is larger than that of non-resource FDI.

The above results may suffer from an endogeneity problem, as FDI and economic growth could have a reverse causality resulting from an endogenous FDI determination. Conventional FDI theories postulate that developed countries direct their investment to poorer economies that have a high return on capital Edwards (1990). Thus, any unobserved factor that increases the rate of return on capital will foster economic growth and attract more FDI. In this case, there would be a correlation between FDI and the error term, which leads to a biased estimated coefficient Borensztein et al. (1998). Two methods are applied that could control for the possible endogeneity: the IV and LIML estimations. It is difficult to find effective instruments that satisfy the no correlation with the error term, but the correlation with FDI Wooldridge (2010).

Following Alfaro (2003), Alfaro (2004), Borensztein et al. (1998), lagged values are used for resource and non-resource FDI as instrumental variables, as lagged values are arguably exogenous. The instruments also include the $\log$ value of the land area and political/institutional variables (political instability and corruption perception index) Wang (2009), Wang \& Sunny Wong (2009), Wang \& Wong (2009). We additionally perform the Sargan test and the C-D test to ensure that the instruments are acceptable.

Table 4 reports IV and LIML estimates. The negative impact of resource-FDI is greater than the coefficient in FE and RE estimations. Table 4 column 3 shows that the growth of GDP per Capita falls by about 0.508 percent when oil sector FDI increases by 1 percent, while again, non-resource FDI inflows have no significant effect on economic growth. The Sargan test demonstrates that the instruments are valid. This validity is confirmed by the C-D statistic, in which the C-D statistic 12.25 is greater than the critical values at 5 percent (10.20). 
Table 4. Economic sectors' FDI and economic growth estimations (IV and LIML).

\begin{tabular}{|c|c|c|c|c|}
\hline VARIABLES & $\begin{array}{r}(1) \\
I V \\
\text { GDP Per } \\
\text { Capita growth }\end{array}$ & $\begin{array}{r}(2) \\
\text { LIML } \\
\text { GDP Per } \\
\text { Capita growth }\end{array}$ & $\begin{array}{r}(3) \\
I V \\
\text { GDP Per } \\
\text { Capita growth }\end{array}$ & $\begin{array}{r}(4) \\
\text { LIML } \\
\text { GDP Per } \\
\text { Capita } \\
\text { growth }\end{array}$ \\
\hline $\log (F D I N R / G D P)$ & $\begin{array}{r}-0.0452 \\
(0.0515)\end{array}$ & $\begin{array}{r}-0.0464 \\
(0.0626)\end{array}$ & & \\
\hline Initial GDP & $\begin{array}{r}-0.777 * * * \\
(0.145)\end{array}$ & $\begin{array}{r}-0.120 * * \\
(0.0573)\end{array}$ & $\begin{array}{r}-0.778 * * * \\
(0.153)\end{array}$ & $\begin{array}{r}-0.0819 \\
(0.0726)\end{array}$ \\
\hline Log (capital formation) & $\begin{array}{r}0.177 * \\
(0.0969)\end{array}$ & $\begin{array}{l}0.134 * * \\
(0.0621)\end{array}$ & $\begin{array}{r}0.00977 * \\
(0.122)\end{array}$ & $\begin{array}{r}0.0763 \\
(0.0717)\end{array}$ \\
\hline Log (population growth) & $\begin{array}{r}0.0151 \\
(0.0411)\end{array}$ & $\begin{array}{r}0.0280 \\
(0.0633)\end{array}$ & $\begin{array}{r}-0.0746 \\
(0.0555)\end{array}$ & $\begin{array}{c}0.00145 \\
(0.0406)\end{array}$ \\
\hline Log (consumption) & $\begin{array}{r}0.303 * * \\
(0.120)\end{array}$ & $\begin{array}{c}-0.0816^{*} \\
(0.0444)\end{array}$ & $\begin{array}{r}0.776^{* * * *} \\
(0.289)\end{array}$ & $\begin{array}{r}0.0635 \\
(0.0555)\end{array}$ \\
\hline $\log (F D I R / G D P)$ & & & $\begin{array}{r}-0.508 * \\
(0.279)\end{array}$ & $\begin{array}{r}-0.0686 * \\
(0.101)\end{array}$ \\
\hline Constant & & $\begin{array}{r}0.198 \\
(0.354) \\
\end{array}$ & & $\begin{array}{r}0.326 \\
(0.251) \\
\end{array}$ \\
\hline$R$-squared & 0.444 & 0.115 & 0.334 & 0.199 \\
\hline Sargan test ( $p$-value) & $3.95(0.13)$ & --- & $0.633(.72)$ & --- \\
\hline Cragg-Donald statistic & 12.25 & --- & 10.67 & --- \\
\hline $\begin{array}{l}\text { Endogeneity test of endogenous } \\
\text { regressor (FDI"Resource and } \\
\text { non-Resource") }\end{array}$ & $\begin{array}{r}10.502 \\
(0.013)\end{array}$ & --- & --- & --- \\
\hline Observations & 54 & 54 & 54 & 54 \\
\hline Number of $N$ & 6 & 6 & 6 & 6 \\
\hline
\end{tabular}

Note: (1) Standard errors in parentheses $* * * \mathrm{p}<0.01, * * \mathrm{p}<0.05, * \mathrm{p}<0.1$ (2) FDIR indicates FDI in the resource sector and FDINR refers to FDI in the non-resource sector. (3) The endogeneity test is for testing whether the variable of interest is endogenous or not. This test based on the outcomes of the IV(xtivreg2 code in SATA.15) regression.

For further robustness, the LIML estimation is applied. Table 4, column 4 confirms the adverse relationship between economic growth and FDI in the oil sector. However, the magnitude of the coefficient is lower compared to the IV coefficient. The possible reasons for this negative relationship are clarified in the discussions.

\subsection{Aggregate FDI-economic growth nexus}

The impact of total FDI, resource and non-resource Greenfield, on economic growth, is tested to identify if the negative effects of resource FDI inflows dominate the total effect of FDI. In other words, we investigate whether there is a 'resource curse' for aggregate FDI.

Table 5 shows the re-estimated model using total Greenfield FDI with FE, RE, IV, and LIML estimations, where the total FDI has a negative and significant impact on economic growth.

Columns 1 and 2 include all the variables using FE and RE models. The Hausman test suggests that the FE model is accepted as the null hypothesis is rejected at 5 percent, and there is a negative and statistically significant relationship between total Greenfield FDI and economic growth. FDI inflows increase by 1 percent; economic growth falls by 0.135 percent.

Robustness tests are done, and the exogeneity of independent variables is checked. FDI may be an endogenous variable, and hence endogeneity test is performed and confirmed that FDI is endogenous. We instrumentalise FDI by using lagged FDI, political instability and corruption perception index. Applying the Sargan test, the Sargan statistic is insignificant, which means rejection of the null hypothesis (that instruments are over-identified). The C-D 
Table 5. Total FDI and economic growth estimations.

\begin{tabular}{|c|c|c|c|c|}
\hline & $\begin{array}{r}(1) \\
F E \\
\text { GDP Per } \\
\text { Capita } \\
\text { growth }\end{array}$ & $\begin{array}{r}(2) \\
R E \\
\text { GDP Per } \\
\text { Capita } \\
\text { growth }\end{array}$ & $\begin{array}{r}(3) \\
I V \\
\text { GDP Per } \\
\text { Capita } \\
\text { growth }\end{array}$ & $\begin{array}{r}(4) \\
\text { LIML } \\
\text { GDP Per } \\
\text { Capita } \\
\text { growth }\end{array}$ \\
\hline$G D P$ initial & $\begin{array}{r}-0.808 * * * \\
(0.102)\end{array}$ & $\begin{array}{r}-0.0847 \\
(0.0600)\end{array}$ & $\begin{array}{r}-0.791 * * * \\
(0.120)\end{array}$ & $\begin{array}{l}-0.0757 \\
(0.0580)\end{array}$ \\
\hline $\log ($ Total FDI/GDP $)$ & $\begin{array}{r}-0.135 * * * \\
(0.0224)\end{array}$ & $\begin{array}{r}-0.0341 * * \\
(0.0159)\end{array}$ & $\begin{array}{r}-0.245 * * * * \\
(0.0839)\end{array}$ & $\begin{array}{r}-0.0470 * \\
(0.0247)\end{array}$ \\
\hline Log (capital formation) & $\begin{array}{r}0.112 * \\
(0.0644)\end{array}$ & $\begin{array}{r}0.0832 \\
(0.0586)\end{array}$ & $\begin{array}{r}0.0784 \\
(0.0796)\end{array}$ & $\begin{array}{r}0.0736 \\
(0.0569)\end{array}$ \\
\hline Log (population growth) & $\begin{array}{r}-0.0306 \\
(0.0266)\end{array}$ & $\begin{array}{r}0.0101 \\
(0.0420)\end{array}$ & $\begin{array}{r}-0.0521 \\
(0.0348)\end{array}$ & $\begin{array}{r}0.0160 \\
(0.0404)\end{array}$ \\
\hline Log (consumption) & $\begin{array}{r}0.531 * * * \\
(0.0951)\end{array}$ & $\begin{array}{r}-0.0635 \\
(0.0451)\end{array}$ & $\begin{array}{r}0.710 * * * \\
(0.171)\end{array}$ & $\begin{array}{r}-0.0561 \\
(0.0439)\end{array}$ \\
\hline Constant & $\begin{array}{r}-3.084 * * * \\
(0.646) \\
\end{array}$ & $\begin{array}{r}0.287 \\
(0.253) \\
\end{array}$ & & $\begin{array}{r}0.266 \\
(0.239) \\
\end{array}$ \\
\hline $\begin{array}{l}\text { R-squared } \\
\text { Hausman test } \\
\text { Chi2 (p-value }\end{array}$ & $\begin{array}{r}0.741 \\
47.92 \\
(0.000)\end{array}$ & & 0.592 & 0.188 \\
\hline $\begin{array}{l}\text { Sargan test (p-value) } \\
\text { Cragg-Donald statistic }\end{array}$ & --- & $\begin{array}{l}--- \\
---\end{array}$ & $\begin{array}{r}0.715(0.69) \\
11.45\end{array}$ & --- \\
\hline $\begin{array}{l}\text { Endogeneity test of endogenous } \\
\text { regressor (FDI"resource and } \\
\text { non-resource") }\end{array}$ & --- & --- & $3.03(0.081)$ & --- \\
\hline $\begin{array}{l}\text { Observations } \\
\text { Number of } N\end{array}$ & $\begin{array}{r}54 \\
6\end{array}$ & $\begin{array}{r}54 \\
6\end{array}$ & $\begin{array}{r}54 \\
6\end{array}$ & $\begin{array}{r}54 \\
6\end{array}$ \\
\hline
\end{tabular}

Note: (1) Standard errors in parentheses $* * * \mathrm{p}<0.01$, ** $\mathrm{p}<0.05, * \mathrm{p}<0.1$ (2) FDIR indicates FDI in the resource sector and FDINR refers to FDI in the non-resource sector. (3) The endogeneity test is for testing whether the variable of interest is endogenous or not. This test based on the outcomes of the IV(xtivreg2) regression.

test was applied to check the strengths of the instrumental variables and showed F statistic is 11.45, greater than the Stock-Yogo critical values, at 10 percent (9.08).

Table 5 column 3 for applying the IV estimation, the negative effect becomes greater in magnitude, and economic growth drops by 0.24 percent if FDI rise by 1 percent. The LIML estimates confirm the adverse effect of FDI, and the coefficient is significant at 10 percent.

Table 5 column 1, shows that, for other control variables, initial GDP has a negative and significant effect on economic growth with the estimated coefficient on initial GDP, $0.800 * * *$

(s.e. $=0.113)$. The convergence rate is 8.00 percent per year and predicts higher growth in response to lower starting GDP per person, only if the other explanatory variables (some of which are highly correlated with GDP per person) are held constant. The impact of initial GDP per Capita is consistent for all the estimators. These results are consistent with past studies, of Alfaro et al. (2004), Borensztein et al. (1998).

Gross capital formation (domestic capital) as a determinant of FDI, has a significant and positive effect on economic growth, and higher domestic investment promotes economic growth. 


\subsection{Discussions}

Resource-FDI inflows hinder economic growth in GCC economies, while non-resource FDI has an insignificant effect on growth Alfaro (2003), Vu and Noy (2009), Aykut and Sayek, (2007), and Khaliq and Noy (2007). The results show that FDI in resource-rich economies can be a causal factor in the resource curse Asiedu (2013), Asiedu and Lien (2011), Poelhekke and Van der Ploeg (2010), Poelhekke and van der Ploeg (2013).

Sachs and Warner (2001), argued that extractive industries might hurt the local economy. The change in local market structures because of the incoming investment flows could raise rent-seeking activity and cause the institutions of the local economy to deteriorate (a variant of the 'resource curse').

This result gives evidence of the crowding-out effect of resource-FDI. This study supports previous literature, such as Mencinger (2003), Smarzynska Javorcik (2004).

\section{Conclusion and policy implications}

Both resource-FDI and total Greenfield FDI inflows hinder economic growth in the GCC economies, while non-resource FDI has an insignificant effect on growth. These results give evidence on the crowding-out effect of resource-FDI.

These findings provide significant support for the natural resource curse. From the FDI determinant side, this paper gives evidence on the FDI-natural resource curse, supporting the results of other researchers. Based on the resource and aggregate FDI impacts dimension, this study supports the negative effect of FDI on economic growth results.

The resource-rich and the GCC economies should seek to increase the degree of FDI diversification, and improve the quality of institutions, to improve the efficiency of attracting and benefiting from FDI and foreign firms. The GCC economies provide incentives for foreign investors; however, in order to improve FDI spillovers, more openness, improved education and well-developed financial sectors are necessary.

It is essential to improve domestic conditions to establish equitable linkages, improve domestic firms, benefit from the technological know-how and improve the country's export. Further, these countries should adopt screening policies to guarantee that FDI does not displace domestic firms. This process requires administrative skills to implement effective screening policies.

Finally, further analytical work is needed to develop a deeper understanding of FDI in resource-rich economies. First, this study was constrained by a specific sample, and it would be better to expand this sample. Using different proxies for natural resources could give different results. Also, if data on the firm-level were available for the host economies, this would appear to be the best way forward for providing an improved understanding of the issues and dimensions of economic sectors' FDI inflows. Furthermore, our study is limited to a specific period; due to the limitations of the dataset. The data on economic sectors' FDI is not free access. It would be useful to replicate this estimation with a longer period or quarterly dataset.

In addition, Extreme Bound Analysis (EBA) or the later proposed Dynamic Extreme Bound Analysis (DEBA), should be used to identify the determinants to be used in the model. Future work may expand the analysis to include these determinants to reduce the possibility of the sensitivity to the choice of variables.

\section{References}

Agyapong, D., and Bedjabeng, K. A. (2019) External debt stock, foreign direct investment and financial development, Journal of Asian Business and Economic Studies, 27(1), 8198. 
Aitken, B. J., and Harrison, A. E. (1999) Do domestic firms benefit from direct foreign investment? Evidence from Venezuela, American Economic Review, 89(3), 605-618.

Alfaro, L. (2003). Foreign direct investment and growth: Does the sector matter? Harvard Business School, Mimeo, Boston, MA, 1-31.

Alfaro, L., Chanda, A., Kalemli-Ozcan, S., and Sayek, S. (2004) FDI and economic growth: the role of local financial markets, Journal of International Economics, 64(1), 89-112.

Anderson, T. W., and Rubin, H. (1950) The asymptotic properties of estimates of the parameters of a single equation in a complete system of stochastic equations, The Annals of Mathematical Statistics, 21(4), 570-582.

Anderson, T., Kunitomo, N., and Matsushita, Y. (2010) On the asymptotic optimality of the LIML estimator with possibly many instruments, Journal of Econometrics, 157(2), 191204.

Andrews, D. W., and Stock, J. H. (2005) Identification and Inference for Econometric Models: Essays in Honor of Thomas Rothenberg: Cambridge University Press.

Arellano, M., and Bond, S. (1991) Some tests of specification for panel data: Monte Carlo evidence and an application to employment equations, The Review of Economic Studies, 58(2), 277-297.

Asiedu, E. (2013) Foreign direct investment, natural resources and institutions. International Growth Centre, Working paper, London School of Economics and Politics. Available at theigc.org/wp-content/uploads/2014/09/Asiedu-2013-Working-Paper.pdf

Asiedu, E., and Lien, D. (2011) Democracy, foreign direct investment and natural resources, Journal of International Economics, 84(1), 99-111.

Aykut, D., and Sayek, S. (2007) The role of the sectoral composition of foreign direct investment on growth, Do multinationals feed local development and growth, International Business and Management, 35-62.

Azman-Saini, W., Law, S. H., and Ahmad, A. H. (2010) FDI and economic growth: New evidence on the role of financial markets, Economics Letters, 107(2), 211-213.

Balasubramanyam, V. N., Salisu, M., \& Sapsford, D. (1996) Foreign direct investment and growth in EP and IS countries, The Economic Journal, 92-105.

Baltagi, B. (2008) Econometric analysis of panel data (Vol. 1), John Wiley and Sons.

Blomquist, S., and Dahlberg, M. (1999) Small sample properties of LIML and jackknife IV estimators: experiments with weak instruments, Journal of Applied Econometrics, 14(1), 69-88.

Blomström, M., Kokko, A., and Globerman, S. (2001) The determinants of host country spillovers from foreign direct investment: a review and synthesis of the literature, In Inward Investment Technological Change and Growth (pp. 34-65): Springer.

Blundell, R., \& Bond, S. (1998) Initial conditions and moment restrictions in dynamic panel data models, Journal of Econometrics, 87(1), 115-143.

Borensztein, E., De Gregorio, J., and Lee, J.-W. (1998). How does foreign direct investment affect economic growth? Journal of International Economics, 45(1), 115-135.

Cameron, A. C. (2010) Microeconometrics using Stata (Vol. 2): Stata Press College Station, TX.

Campos, N. F., and Kinoshita, Y (2003) Why Does FDI Go Where it Goes? New Evidence from the Transition Economies, International Monetary Fund, Working Paper No. 03/228. Available at https://www.imf.org/external/pubs/ft/wp/2003/wp03228.pdf

Carkovic, M. V., and Levine, R. (2002) Does foreign direct investment accelerate economic growth? http://siteresources.worldbank.org/INTFR/Resources/fdi.pdf

Cazzavillan, G., and Olszewski, K. (2012) Interaction between foreign financial services and foreign direct investment in Transition Economies: An empirical analysis with focus on the manufacturing sector, Research in Economics, 66(4), 305-319. 
Dobson, S., \& Ramlogan-Dobson, C. (2012) Why is corruption less harmful to income inequality in Latin America?, World Development, 40(8), 1534-1545.

Edwards, S. (1990) Capital flows, foreign direct investment, and debt-equity swaps in developing countries, NBER working paper no. 3497. Cambridge, MA: NBER. Available at https://www.nber.org/papers/w3497.pdf

El Heddad, M. (2016) Natural Resource and FDI in GCC countries International Journal of Business and Social Research, Vol. 6, Issue 7.

fDiintelligence. (2015) Foreign Direct Investment into GCC countries, In F. T. Ltd (Ed.). London: Financial Times.

Haddad, M., and Harrison, A. (1993) Are there positive spillovers from direct foreign investment? Evidence from panel data for Morocco, Journal of Development Economics, 42(1), 51-74.

Hausman, J. A. (1978) Specification tests in econometrics. Econometrica, Journal of the Econometric Society, 46(6) 1251-1271.

Hsiao, C. (2007) Panel data analysis - advantages and challenges. Test, 16(1), 1-22.

Khaliq, A and Noy, I. (2007) Foreign Direct Investment and Economic Growth: Empirical Evidence from Sectoral Data in Indonesia, Working Papers. No 200726, the University of Hawaii at Manoa, Department of Economics, https://EconPapers.repec.org/RePEc:hai:wpaper:200726

Khaliq, A., and Noy, I. (2007) Foreign direct investment and economic growth: Empirical evidence from sectoral data in Indonesia, Journal of Economic Literature, 45(1), 313-325.

Kolstad, I., and Villanger, E. (2008) Determinants of foreign direct investment in services, European Journal of Political Economy, 24(2), 518-533.

Mencinger, J. (2003) Does foreign direct investment always enhance economic growth? Kyklos, 56(4), 491-508.

Nasir, M. A., Huynh, T. L. D., and Tram, H. T. X. (2019) Role of financial development, economic growth \& foreign direct investment in driving climate change: A case of emerging ASEAN, Journal of environmental management, 242, 131-141.

Nasir, M. A., Huynh, T. L. D., and Yarovaya, L. (2020) Inflation targeting \& implications of oil shocks for inflation expectations in oil-importing and exporting economies: Evidence from three Nordic Kingdoms, International Review of Financial Analysis, 72, 101558.

Nasir, M. A., Balsalobre-Lorente, D., \& Huynh, T. L. D. (2020) Anchoring inflation expectations in the face of oil shocks \& in the proximity of ZLB: A tale of two targeters, Energy Economics, 86, 104662.

Pham. H., Wongsurawat. W. (2020) FDI determinants: dynamic extreme bounds analysis, International Journal of Emerging Markets.

Poelhekke, S., and Van der Ploeg, R. (2010) Do Natural Resources Attract FDI? Evidence from non-stationary sector-level data, DNB Working Papers, Working Paper No. 266.

Poelhekke, S., and van der Ploeg, R. (2013) Do Natural Resources Attract Non resource FDI?, The Review of Economics and Statistics 95(3), 1047-1065.

Roodman, D. (2009) How to do xtabond2: An introduction to difference and system GMM in Stata, Stata Journal, 9(1), 86-136.

Sachs, J. D., and Warner, A. M. (2001) The curse of natural resources, European Economic Review, 45(4), 827-838.

Sadik, A. T., and Bolbol, A. A. (2001). Capital flows, FDI, and technology spillovers: evidence from Arab countries, World Development, 29(12), 2111-2125.

Sala-i-Martin, X, (1997). 'I Just Ran Two Million Regressions' American Economic Review, 87, 178-183 
Smarzynska Javorcik, B. (2004) Does foreign direct investment increase the productivity of domestic firms? In search of spillovers through backward linkages, American Economic Review, 94(3), 605-627.

UNCTAD. (2016). UNCTAD dataset.

$\mathrm{Vu}, \mathrm{T}$. B., Gangnes, B., and Noy, I. (2008) Is foreign direct investment good for growth? Evidence from sectoral analysis of China and Vietnam, Journal of the Asia Pacific Economy, 13(4), 542-562.

$\mathrm{Vu}, \mathrm{T}$. B., and Noy, I. (2009) Sectoral analysis of foreign direct investment and growth in developed countries, Journal of International Financial Markets, Institutions and Money, 19(2), 402-413.

Wallis, K. F. (1968) The EEC and United States foreign investment: some empirical evidence re-examined, Economic Journal, 717-719.

Wang, M. (2009) Manufacturing FDI and economic growth: evidence from Asian economies, Applied Economics, 41(8), 991-1002.

Wang, M., \& Sunny Wong, M. (2009) What drives economic growth? The case of crossborder M\&A and greenfield FDI activities, Kyklos, 62(2), 316-330.

Wang, M., \& Wong, M. S. (2009) Foreign direct investment and economic growth: The growth accounting perspective, Economic Inquiry, 47(4), 701-710.

Wooldridge, J. M. (2010) Econometric analysis of cross section and panel data: MIT press. World Bank. (2018) World Development Indicators. In W. Bank (Ed.). Washington, D. 